\title{
ANALISA KESEHATAN MANGROVE BERDASARKAN NILAI NORMALIZED DIFFERENCE VEGETATION INDEX MENGGUNAKAN CITRA ALOS AVNIR-2
}

\author{
Tyas Eka Kusumaningrum, Bangun Muljo Sukojo \\ Jurusan Teknik Geomatika, Fakultas Teknik Sipil dan Perencanaan, Institut Teknologi Sepuluh Nopember (ITS) \\ Jl. Arief Rahman Hakim, Surabaya 60111 \\ e-mail: bangunms@gmail.com
}

\begin{abstract}
Abstrak
Pesisir Kota Surabaya merupakan daerah lahan basah yang memiliki keanekaragaman ekosistem, baik ekosistem pasir, ekosistem rawa payau, dan ekosistem mangrove. Ekosistem mangrove adalah salah satu obyek yang bisa diindentifikasi dengan menggunakan teknologi penginderaan jauh. Data yang digunakan dalam penelitian ini adalah citra satelit ALOS AVNIR-2 tahun 2009. Dalam menentukan tingkat kesehatan vegetasi mangrove di daerah penelitian, digunakan algoritma Indeks Vegetasi Normalized Difference Vegetation Index (NDVI).
\end{abstract}

Berdasarkan hasil penelitian, korelasi antara NDVI dengan nilai Spektral Ground yaitu 0.817. Hasil korelasi tersebut termasuk korelasi sangat kuat (0.80-1.00). Koefisien korelasi bertanda positif artinya hubungan nilai NDVI pada citra dengan Spektral Ground satu arah, sehingga jika nilai NDVI tinggi (kesehatan vegetasi normal), maka nilai Spektral Ground juga semakin tinggi. Dari hasil klasifikasi vegetasi mangrove berdasarkan nilai NDVI didapatkan kelas vegetasi mangrove dengan kondisi kesehatan rusak (70\%) yang didominasi pada Kecamatan Krembangan, sangat buruk $(17,7 \%)$ terletak di Kecamatan Kenjeran, buruk (7\%) terletak di Kecamatan Mulyorejo, dan normal (5,3\%) terletak di Kecamatan Rungkut dan Gunung Anyar.

Kata kunci--Mangrove, ALOS AVNIR-2, NDVI

\section{PENDAHULUAN}

Wilayah pesisir Kota Surabaya secara umum dapat dikelompokkan menjadi kawasan pesisir utara dan timur. Wilayah pesisir memiliki ekosistem yang dinamis dan mempunyai kekayaan habitat yang beragam di darat maupun di laut yang saling berinteraksi. Dinamika wilayah pesisir tergantung dari jenis pantai dan prosesproses yang menyertainya. Selain itu, secara alami di wilayah pesisir sangat dipengaruhi oleh keberadaan ekosistem penyangga berupa terumbu karang dan mangrove. Secara fisik, hutan mangrove menjaga garis pantai agar tetap stabil melindungi pantai, tebing sungai, mencegah intrusi air garam ke darat, sebagai perangkap zat-zat pencemar dan limbah serta sebagai kawasan penahan air [1].

Kawasan penahan air yaitu kawasan pantai yang yang menjadi tempat penampungan sementara air hujan sebelum mengalir ke laut. Kawasan penahan air yang

diubah menjadi kawasan pemukiman akan menyebabkan hilangnya daerah penahan air sehingga ketika musim hujan tiba air yang akan ke laut menggenang di tengah-tengah kota dan menyebabkan banjir. Pantai Timur Surabaya adalah salah satu contoh kawasan penahan air yang akan bermuara ke laut.

Pesisir Surabaya Utara, kondisi mangrove dalam kondisi kesehatan rusak. Hal ini dapat dikarenakan desakan pembangunan yang menjadi penyebab terancamnya keberadaan mangrove di Pesisir Surabaya Utara. Pembangunan Pelabuhan, Industri, Pergudangan dan Tambak mengancam keberadaan mangrove di Pesisir Surabaya Utara serta pembabatan mangrove masih terus terjadi.

Pantai Timur Surabaya merupakan daerah lahan basah yang memiliki keanekaragaman ekosistem, baik ekosistem pasir, ekosistem rawa payau dan ekosistem mangrove dengan luas mencapai 3.129 ha pada tahun 1998. Sejak tahun 1993, setelah kawasan Pantai Timur Surabaya diubah peruntukannya menjadi kawasan pengembangan yang sebelumnya dalam masterplan 2000 ditetapkan sebagai kawasan konservasi, selama kurun waktu lima tahun telah terjadi pengalihan 
fungsi lahan secara revolusi. Kesinambungannya sangat dipengaruhi oleh keberadaan ekosistem mangrove yang menjadi penghubungnya. Kawasan Pantai Timur Surabaya sebenarnya daerah penyangga yang dapat dikembangkan menjadi kawasan hutan kota karena di kawasan ini telah ada hutan mangrove namun kondisinya yang perlu untuk dibenahi kembali [2].

Ekosistem mangrove adalah salah satu obyek yang bisa di indentifikasi dengan menggunakan teknologi penginderaan jauh. Letak geografi ekosistem mangrove yang berada pada daerah peralihan darat dan laut memberikan efek perekaman yang khas jika dibandingkan obyek vegetasi darat lainnya. Efek perekaman tersebut sangat erat kaitannya dengan karakteritik spektral ekosistem mangrove, hingga dalam identifikasi memerlukan suatu transformasi tersendiri. Pada umumnya untuk deteksi vegetasi digunakan transformasi indeks vegetasi [3]. Dalam penelitian ini akan mengkaji tingkat kesehatan vegetasi mangrove berdasarkan nilai Normalized Difference Vegetation Index (NDVI) menggunakan teknik penginderaan jauh dengan menggunakan citra satelit ALOS AVNIR-2 Tahun 2009. Selain itu dalam penelitian ini nilai NDVI citra ALOS AVNIR-2 divalidasi dengan nilai Spektral Ground menggunakan kamera Inframerah.

Dari hasil penelitian ini diharapkan memberikan suatu informasi mengenai tingkat kesehatan dan kondisi vegetasi mangrove yang didasarkan pada pengolahan citra ALOS AVNIR-2, sehingga dapat dijadikan sebagai bahan referensi penelitian yang terkait dengan bidang kesehatan vegetasi mangrove.

\section{METODOLOGI PENELITIAN}

Lokasi Penelitian

Lokasi penelitian tugas akhir ini termasuk di daerah kesesuaian lahan untuk konservasi mangrove yang secara administratif terletak di wilayah pesisir Kota Surabaya yang meliputi kawasan pesisir utara dan timur. Secara geografis daerah studi ini terletak pada koordinat antara $7^{0} 14^{\prime} 0^{\prime \prime}-7^{0} 21^{\prime} 0^{\prime \prime}$ LS dan $112^{\circ} 37^{\prime} 0^{\prime \prime}-$ $112^{\circ} 57^{\prime} 0^{\prime \prime}$ BT.

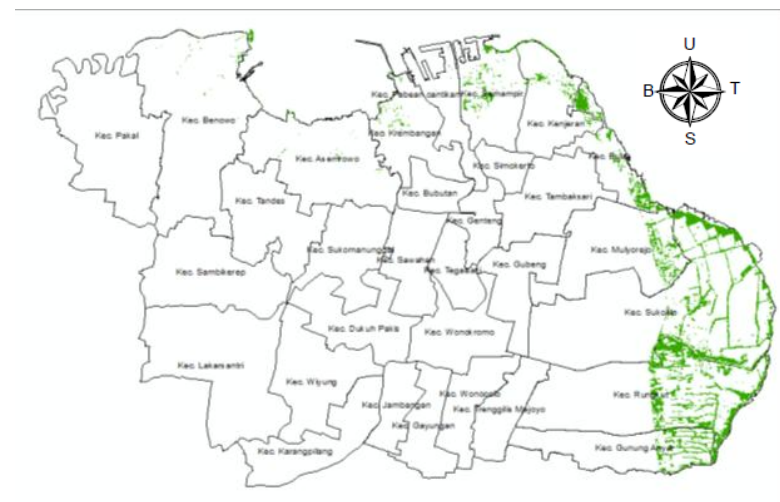

Lokasi Penelitian

Gambar 1. Lokasi Penelitian

Data dan Perangkat Lunak

Data yang digunakan dalam penelitian ini adalah:

Citra ALOS AVNIR-2 tahun 2009.

Citra Landsat 7 ETM+ Orthormetrik tahun 2001.

Data Spektral Ground yang diperoleh dari pengambilan foto di lapangan menggunakan kamera Inframerah.

Peta Kesesuaian Lahan untuk Konservasi Mangrove tahun 2009.

\section{Tahapan Pengolahan Data}

Tahapan yang dilaksanakan dalam pengolahan data yaitu sebagai berikut :

Berdasarkan diagram alir diatas, secara umum penelitian ini dibagi menjadi tahapan sebagai berikut:

Tahap Awal, dimana meliputi proses koreksi geometrik pada citra ALOS AVNIR-2 untuk mereduksi kesalahan geometrik yang terjadi pada citra, sehingga dihasilkan citra terkoreksi geometrik. Proses cropping atau pemotongan citra dilakukan untuk membatasi daerah kajian sekaligus meringankan proses pengolahan data agar pemrosesan data menjadi lebih efektif.

Tahap Pengolahan, dimana dilakukan penerapan algoritma Indeks Vegetasi. Dalam penelitian ini menggunakan algoritma Normaized Difference Vegetation Index (NDVI). Algoritma NDVI sebagai berikut :

Keterangan :

$$
\begin{aligned}
& N D V I=\rho \text { NIR }-\rho \text { RED } \\
& \rho N I R+\rho \text { RED }
\end{aligned}
$$

$\rho$ NIR $=$ Band Inframerah Dekat

$\rho$ RED $=$ Band Merah 


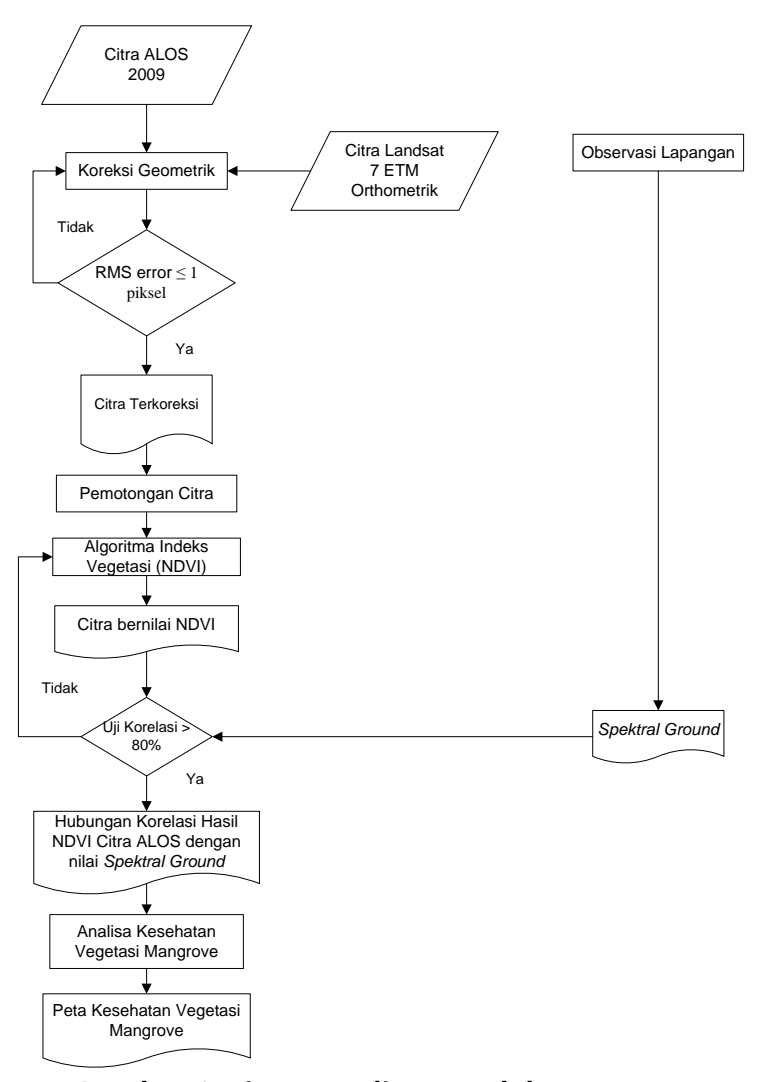

Gambar 2.Diagram Alir Pengolahan Data

Dari hasil penerapan algoritma tersebut akan menghasilkan nilai spektral antara - 1 sampai dengan 1. Selanjutnya, dilakukan klasifikasi terselia dengan memasukkan range nilai tiap jenis kesehatan vegetasi mangrove [4]. Selain itu dilakukan observasi lapangan untuk mendapatkan data Spektral Ground menggunakan kamera Inframerah dimana data Spektral Ground digunakan sebagai data validasi.

Tabel 1. Hubungan Nilai NDVI dengan Kesehatan dan Kepadatan Tanaman

\begin{tabular}{ll}
\hline \hline $\begin{array}{l}\text { Kesehatan Tanaman \& } \\
\text { Kepadatan Tanaman }\end{array}$ & Nilai NDVI \\
\hline Sangat Baik & $0,72-0,92$ \\
Baik & $0,42-0,72$ \\
Normal & $0,22-0,42$ \\
Buruk & $0,12-0,22$ \\
Sangat Buruk & $-0,1-0,12$ \\
\hline \hline ber http://endeleo.vgt.vito.be/dataproducts.html)
\end{tabular}

Tahap Akhir, dimana pada tahap ini dilakukan uji korelasi antara nilai NDVI dari citra ALOS AVNIR-2 dengan nilai Spektral Ground menggunakan kamera Inframerah sehingga menghasilkan hubungan korelasi hasil NDVI citra ALOS dengan nilai Spektral Ground. Selain itu, analisa juga dilakukan terhadap kesehatan mangrove berdasarkan nilai NDVI.

\section{HASIL DAN PEMBAHASAN}

Pada bagian ini akan ditampilkan hasil dari pelaksanaan penelitian yang telah dilakukan mengenai tingkat kesehatan vegetasi mangrove berdasarkan nilai Normalized Difference Vegetation Index (NDVI).

\section{Hasil Koreksi Geometrik Citra dan SOF}

Koreksi geometrik citra satelit ALOS AVNIR-2 tahun 2009 dilakukan dengan menggunakan Citra Landsat 7 ETM Orthometrik. Hasil koreksi geometrik yang dilakukan dengan 14 titik GCP yang terdistribusi secara merata, dari konfigurasi 14 titik GCP. Hasil koreksi geometrik citra ALOS AVNIR-2 Tahun 2009 dengan rata-rata RMS error sebesar 0,183 dan SOFnya sebesar 0.3767.

\section{Pembagian Wilayah Vegetasi Mangrove di Pesisir Surabaya}

Area studi terdiri dari beberapa wilayah vegetasi dimana pembatasan wilayah vegetasi berdasarkan Bappeko, 2009. Wilayah I, II, dan III (Teluk Lamong atau Pesisir Utara). Penggambaran wilayah tersebut dapat dilihat pada gambar 3 .

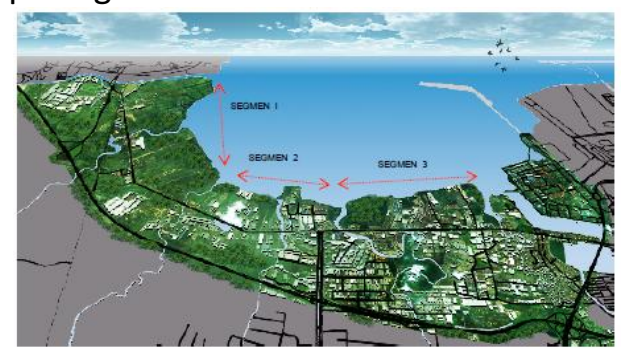

Gambar 3. Wilayah I, II, dan III

Lokasi wilayah IV sampai IX secara berurutan dapat dilihat dalam gambar 4, 5, 6 .

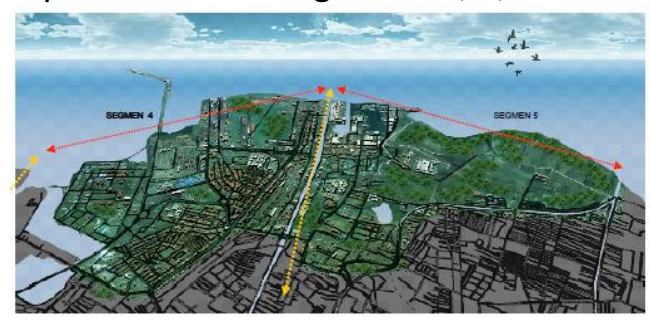

Gambar 4. Wilayah IV dan V 


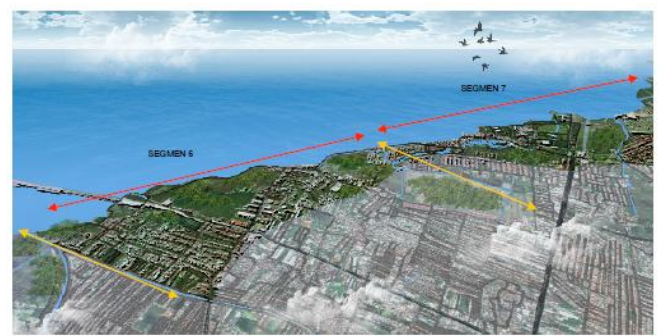

Gambar 5. Wilayah VI dan VII

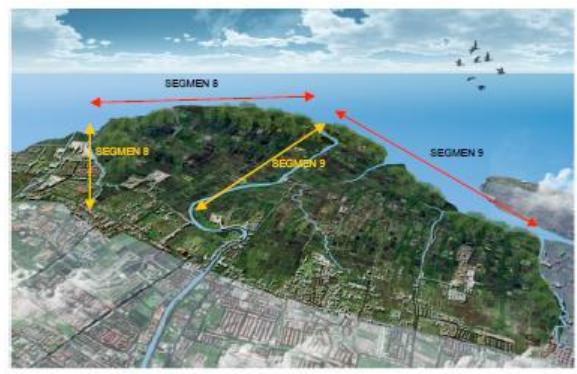

Gambar 6. Wilayah VIII dan IX

Untuk memudahkan dalam melakukan analisa, maka segmen vegetasi tersebut dikelompokkan menjadi empat bagian:

Bagian pertama terdiri dari wilayah I, II, dan III (Kecamatan Asemrowo, Kecamatan Benowo, dan Kecamatan Krembangan)

b. Bagian kedua terdiri dari wilayah IV-V (Kecamatan Pabean Cantikan, Kecamatan Semampir, dan Kecamatan Kenjeran)

c. Bagian ketiga terdiri dari wilayah VI-VII (Kecamatan Bulak dan Kecamatan Mulyorejo)

d. Bagian keempat terdiri dari wilayah VIIIIX (Kecamatan Rungkut, Kecamatan Sukolilo, dan Kecamatan Gunung Anyar)

\section{Klasifikasi Kesehatan Mangrove Berdasarkan Nilai NDVI}

Klasifikasi untuk tingkat kesehatan vegetasi mangrove di wilayah pesisir Kota Surabaya menggunakan klasifikasi tak terbimbing (unsupervised) dengan menggunakan hasil penerapan algoritma NDVI. Berikut hasil penerapan algoritma pada citra ALOS AVNIR-2 Tahun 2009.

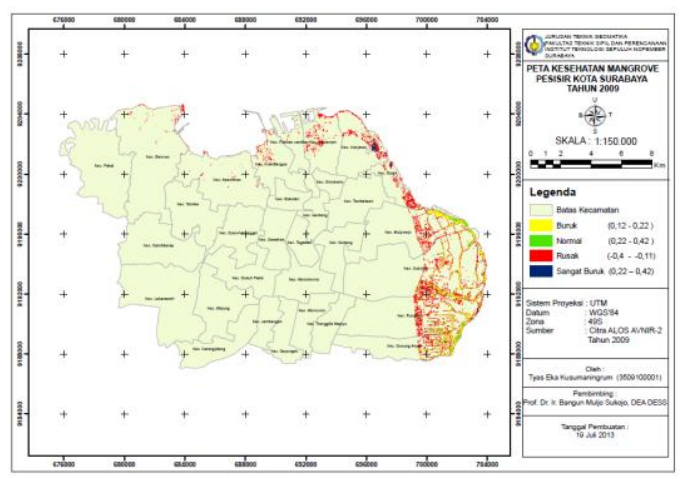

Gambar 7. Peta Kesehatan Vegetasi Mangrove Tahun 2009

Dari hasil klasifikasi vegetasi mangrove berdasarkan nilai NDVI maka dapat diketahui luasan tiap kelas dari hasil klasifikasi tersebut dalam tabel 2 berikut ini :

Tabel 2. Luas (ha) dari Tingkat Kesehatan Mangrove

\begin{tabular}{lllll}
\hline \hline No & Kelas NDVI & $\begin{array}{l}\text { Kesehatan } \\
\text { Vegetasi }\end{array}$ & Luas $\left(\mathrm{m}^{2}\right)$ & $\begin{array}{l}\text { Luas } \\
(\%)\end{array}$ \\
\hline 1 & $-0.4-(-0.11)$ & Rusak & 1272,72 & 70 \\
2 & $-0.100-0.1200$ & Sangat Buruk & 322,23 & 17,7 \\
3 & $0.1210-0.2200$ & Buruk & 126,59 & 7 \\
4 & $0.2210-0.4200$ & Normal & 97,02 & 5,3 \\
Luas Total & & 181856 & 100 \\
\hline \multicolumn{7}{r}{ (Sumber : Hasil pengolahan dan perhitungan) }
\end{tabular}

Berdasarkan tabel 2 Luas Total Mangrove di wilayah pesisir Surabaya Timur dan Surabaya Utara sebesar 1818,56 ha. Dari total luas tersebut 1272,72 ha merupakan daerah mangrove dengan kondisi kesehatan rusak, 322,23 ha merupakan daerah mangrove dengan kondisi kesehatan yang sangat buruk, 126,59 ha merupakan daerah mangrove dengan kondisi kesehatan yang buruk, sedangkan daerah mangrove dengan kondisi kesehatan yang normal hanya seluas 97,02 ha.

Dari hasil nilai prosentase hampir sebagian besar mangrove dalam kondisi yang kurang baik (Rusak $70 \%$, Sangat Buruk 17,7\% dan Buruk 7\%) hal ini menunjukkan kerentanan mangrove di Surabaya karena hanya 5,3\% dalam kondisi normal.

Berdasarkan persebaran wilayah tingkat kesehatan, kondisi mangrove pada wilayah IX khususnya Kecamatan Rungkut dan Kecamatan Gunung Anyar mempunyai tingkat kesehatan yang lebih baik dibandingkan dengan wilayah VIII yaitu Kecamatan Sukolilo dan Kecamatan 
Mulyorejo. Hal ini dapat dikarenakan pada dua kecamatan tersebut merupakan daerah kawasan konservasi mangrove Surabaya sehingga pengelolaan mangrove pada daerah tersebut lebih terkelola dengan baik. Pada wilayah pantai Timur bagian Utara (Kecamatan Sukolilo dan Kecamatan Mulyorejo) kondisi mangrove sangat rentan dengan kondisi kesehatan yang sangat buruk. Hal ini dapat dikarenakan perkembangan perumahan dan pemukiman di wilayah tersebut sangat pesat. Perkembangan perumahan ini menjadikan terdesaknya kawasan mangrove untuk perluasan area perumahan yang mengakibatkan aktivitas mangrove terganggu oleh pencemaran lingkungan.

Sedangkan pada wilayah pesisir utara, kondisi mangrove dalam kondisi kesehatan rusak. Hal ini dapat dikarenakan desakan pembangunan yang menjadi penyebab terancamnya keberadaan mangrove di pesisir utara. Pembangunan Pelabuhan, Industri, Pergudangan dan Tambak mengancam keberadaan mangrove di pesisir utara serta pembabatan mangrove masih terus terjadi.

\section{Analisa Vegetasi}

Komposisi vegetasi mangrove pada daerah penelitian yaitu:

Kecamatan Benowo, Kecamatan Asemrowo, dan Kecamatan Krembangan terdiri dari spesies Avicennia Marina, Avicennia Alba, Rhizopora Mucronata, Rizhopora Apiculata, Sonneratia Alba, Lumnitzera Racemosa. Luas vegetasi mangrove $\pm 41,48$ ha. Kategori kesehatan mangrove yang rusak mendominasi di daerah Teluk Lamong.

Kecamatan Kenjeran dan Kecamatan Bulak terdiri dari spesies Avicennia Marina, Avicennia Alba, Sonneratia Alba, Rizhopora Apiculata, Rizhopora Mucronata, dan Rizhopora Stylosa. Luas vegetasi mangrove $\pm 279,05$ ha. Luas dari masing-masing kategori kesehatan mangrove yaitu Rusak $(240,04$ ha), Buruk (0,31 ha), Sangat Buruk $(38,7$ ha)

Kecamatan Mulyorejo dan Kecamatan Sukolilo terdiri dari spesies Avicennia Marina, Avicennia Alba, Avicennia Marina. Sebagaimana telah dijelaskan sebelumnya, Pakuwon termasuk dalam Kecamatan Sukolilo, serta luas vegetasi mangrove pada segmen tersebut $\pm 660,42$ ha. Luas dari masing-masing kategori kesehatan mangrove yaitu Rusak (419,98 ha), Sangat Buruk (118,85 ha), Buruk (75,69 ha), dan Normal (45,90 ha)

Wonorejo termasuk dalam Kecamatan Rungkut yang terdiri dari spesies Avicennia Marina, Avicennia Officinalis, Rizhopora Apiculata, Sonneratia Alba, Xylocarpus Moluccensis. Luas vegetasi mangrove dalam wilayah ini $\pm 837,61$ ha. Luas dari masing-masing kategori kesehatan mangrove yaitu Rusak (571,22 ha), Sangat Buruk $(164,68$ ha), Buruk (50,59 ha), dan Normal $(51,12$ ha)

\section{Validasi Hasil Pengolahan Citra dengan Data Spektral Ground}

Validasi data dilakukan dengan mengkorelasikan hasil pengolahan citra berdasarkan algoritma NDVI dengan data spektral Ground. Hal ini dilakukan untuk mengetahui berapa prosentase hasil pengolahan citra yang merepresentasikan kondisi sebenarnya di lapangan.

Penentuan analisis korelasi dilakukan dengan cara mengambil secara acak sebanyak 35 titik sampel yang mewakili penyebaran indeks vegetasi pada berbagai kelas. Sampel (Spektral Ground) diambil menggunakan kamera inframerah dan wahana pesawat pada daerah Pakuwon yang berada pada Kecamatan Sukolilo.

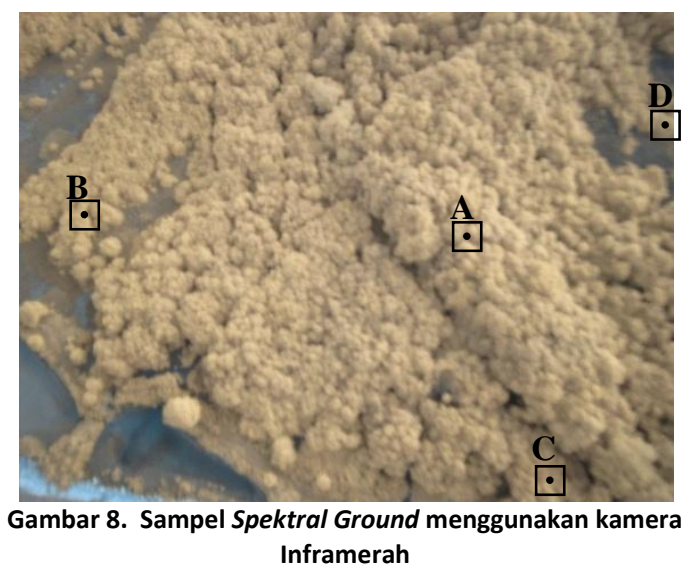

Keterangan: 


$\begin{array}{llll}\text { A }: \text { Normal } & \text { (Nilai } & \text { Spektral } \\ 0,888188) & & \\ \begin{array}{l}\text { B }: \text { Buruk } \\ 0,843307)\end{array} & \text { (Nilai } & \text { Spektral }= \\ \begin{array}{l}\text { C:Sangat Buruk } \\ 0,773228)\end{array} & \text { (Nilai } & \text { Spektral }= \\ \begin{array}{l}\text { D Rusak } \\ 0,746456)\end{array} & \text { (Nilai } & \text { Spektral }=\end{array}$

Sebaran titik yang digunakan dalam uji korelasi yang mendeskripikan hubungan antara nilai NDVI pada citra dengan nilai Spektral Ground, sebagai berikut :

Tabel 3. Data Sebaran Nilai NDVI pada Citra terhadap Spektral di Lapangan

\begin{tabular}{lllll}
\hline \hline No. & Koordinat & & NDVI & FOTO \\
\hline 1 & 701080 & 9194044 & 0,2375 & 0,8692 \\
2 & 701091 & 9193993 & 0,232877 & 0,8629 \\
\hline \hline NO & Koordinat & & NDVI & FOTO \\
\hline 3 & 701223 & 9194278 & 0,225806 & 0,8661 \\
4 & 701253 & 9194309 & 0,24 & 0,8653 \\
5 & 701243 & 9194289 & 0,233766 & 0,8566 \\
6 & 701223 & 9194278 & 0,225806 & 0,8622 \\
7 & 701315 & 9194411 & 0,233766 & 0,8763 \\
8 & 701386 & 9194441 & 0,223684 & 0,8645 \\
9 & 701294 & 9194370 & 0,22973 & 0,8700 \\
10 & 701386 & 9194421 & 0,246753 & 0,8779 \\
11 & 701172 & 9194238 & 0,179856 & 0,8409 \\
12 & 701264 & 9194319 & 0,210884 & 0,8354 \\
13 & 701162 & 9194319 & 0,205882 & 0,8346 \\
14 & 701182 & 9194227 & 0,125828 & 0,8669 \\
15 & 701141 & 9194197 & 0,151079 & 0,8393 \\
16 & 701091 & 9194126 & 0,170068 & 0,8188 \\
17 & 701121 & 9194115 & 0,142857 & 0,8417 \\
18 & 701101 & 9194105 & 0,144928 & 0,8362 \\
19 & 701060 & 9194024 & 0,150327 & 0,8535 \\
20 & 701101 & 9194014 & 0,192053 & 0,8440 \\
21 & 701080 & 9193993 & 0,185714 & 0,8385 \\
22 & 701030 & 9193973 & 0,173913 & 0,8425 \\
23 & 700999 & 9193963 & 0,125 & 0,8496 \\
24 & 701162 & 9194370 & 0,062937 & 0,8086 \\
25 & 701131 & 9194350 & 0,015625 & 0,8259 \\
26 & 70111 & 9194421 & 0,112782 & 0,8149 \\
27 & 701192 & 9194289 & 0,048387 & 0,8118 \\
28 & 701152 & 9194299 & 0,104 & 0,8086 \\
29 & 701406 & 9194543 & 0,066667 & 0,8102 \\
30 & 701386 & 9194523 & 0,071429 & 0,8118 \\
31 & 701396 & 9194492 & 0,028571 & 0,8094 \\
\hline \hline Sumber : Hasil Pengolahandan Perhitungan) & \\
& & & & \\
\hline
\end{tabular}

Nilai koefisien determinasi $\left(R^{2}\right)$ sebesar 0,668 atau koefien korelasinya (R) sebesar 0,817. Sehingga dapat dikatakan antara nilai hasil prediksi dan hasil pengukuran lapangan berkolerasi sebesar $82 \%$.
Hasil analisis korelasi apabila ditinjau dari tingkat hubungan korelasi, hasil penelitian termasuk korelasi sangat kuat $(0,80-1,00)$. Koefisien korelasi bertanda positif artinya hubungan nilai NDVI pada citra dengan Spektral Ground satu arah, sehingga jika nilai NDVI tinggi (kesehatan vegetasi normal), maka nilai Spektral Ground juga semakin tinggi. Hasil korelasi dapat dilihat dalam gambar 8 .

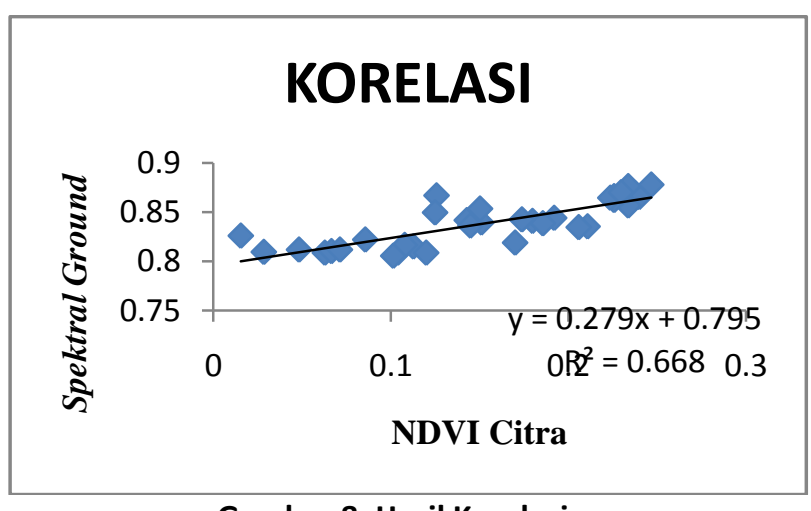

Gambar 8. Hasil Korelasi

Faktor Yang Mempengaruhi Kesehatan
Mangrove Jenis Tanah

Berdasarkan hasil pengolahan didapat bahwa mangrove pada daerah aliran sungai dan muara sungai mempunyai tingkat kesehatan yang lebih baik daripada mangrove pada area pertambakan. Hal ini dapat dikarenakan kondisi tanah pada daerah aliran sungai dan muara sungai mengandung nutrisi organik yang dibawa oleh aliran sungai dari daratan. Mangrove pada daerah aliran sungai yang cukup rimbun menunjukkan tingkat kesehatannya baik dan jenis tanah pada daerah tersebut merupakan tanah alluvial hidromorf (mengandung banyak unsur organik).

Pada area pertambakan, kondisi mangrove kurang begitu baik hal ini dapat dikarenakan kurangnya nutrisi karena lebih terserap pada aktivitas pertambakan. Mangrove pada daerah tersebut kurang rimbun sehingga menunjukkan tingkat kesehatann yang kurang baik. Jenis tanah pada daerah pertambakan merupakan tanah aluvial keabu-abuan yang menunjukkan kurangnya nutrisi. 
Tanah hutan mangrove umumnya bertesktur liat, liat berlempung, liat berdebu, dan lempung yang berupa lumpur tebal, dan yang terdapat di bagian tepi-tepi sungai, muara, saluran-saluran air. Wilayah yang baik untuk ditubuhi mangrove adalah Untuk kisaran $\mathrm{pH}$ tanah pada area studi sebesar 4,70-6,90. Berdasarkan tabel 4.7 setiap stasiun diambil tiga sampel. Stasiun I yang terletak di Teluk Lamong kisaran pH antara 5,806,90 . Stasiun II terletak di Pakuwon kisaran $\mathrm{pH}$ antara 4,70-6,50. Stasiun III terletak di daerah Wonorejo mempunyai kisaran $\mathrm{pH}$ antara 5,706,70 . Nilai $\mathrm{pH}$ tanah dikawasan mangrove berbeda-beda, tergantung pada tingkat kerapatan vegetasi yang tumbuh dikawasan tersebut. Jika kerapatan rendah, tanah akan mempunyai nilai $\mathrm{pH}$ yang tinggi. Nilai $\mathrm{pH}$ tidak banyak berbeda, yaitu antara 4,6-6,5 dibawah tegakan jenis Rhizophora sp.

wilayah pantai yang mempunyai sifat air tenang, air payau, endapan lumpur, dan lebar jalur hutan mangrove dipengaruhi oleh tinggi pasang surut.

\section{Derajat Keasaman $(\mathrm{pH})$ dan Salinitas}

Parameter $\mathrm{pH}$ dapat mempengaruhi kondisi mangrove. Pengambilan data $\mathrm{pH}$ dan Salinitas di area studi dilakukan di beberapa lokasi yaitu Teluk Lamong, Pakuwon, dan Wonorejo. Hasil dari pengukuran dapat dilihat pada tabel di bawah ini :

\section{Tabel 4. Hasil Pengukuran pH dan Salinitas}

\begin{tabular}{llllll} 
Stasiun & Sampel & $\begin{array}{l}\text { Air } \\
\mathrm{pH}\end{array}$ & Salinitas & $\mathrm{pH}$ & Salinitas \\
\hline I & 1 & 7,55 & 25,8 & 6,90 & 20,00 \\
Teluk & 2 & 7,18 & 23,8 & 5,80 & 7,57 \\
Lamong & 3 & 7,5 & 30,5 & 6,10 & 8,20 \\
II & 4 & 8,1 & 20,9 & 4,70 & 8,70 \\
Pakuwon & 5 & 8,25 & 19,6 & 6,40 & 14,00 \\
& 6 & 8,18 & 20,7 & 6,50 & 12,10 \\
III & 7 & 7,6 & 21,6 & 5,90 & 8,00 \\
Wonorejo & 8 & 7,65 & 22,2 & 5,70 & 6,25 \\
& 9 & 7,8 & 5,68 & 6,70 & 5,48 \\
\hline \hline
\end{tabular}

Sumber : Hasil Uji Laboratorium Ekologi, Teknik Lingkungan ITS

Pada area studi ini diperoleh nilai $\mathrm{pH}$ air dan tanah. Kisaran pH air sebesar 7,18-8,25. Nilai pH air tertinggi terdapat di daerah Pakuwon, hal ini dikarenakan pengambilan sampel dilakukan disekitar daerah tumbuh kembang mangrove yang baik. Pada tabel 4 setiap stasiun diambil tiga sampel. Stasiun I yang terletak di Teluk
Lamong kisaran pH antara 7,18-7,55. Stasiun II terletak di Pakuwon kisaran pH antara 8,1-8,25. Stasiun III terletak di daerah Wonorejo mempunyai kisaran $\mathrm{pH}$ antara 7,6-7,8. Berdasarkan penelitian sebelumnya [5], salah satu daerah studi dari penelitian tersebut berada di daerah Wonorejo yang termasuk di dalam Kecamatan Rungkut dimana nilai kisaran $\mathrm{pH}$ sebesar 6-8. Jika dibandingkan dengan hasil pengukuran lapangan yang terdapat pada tabel 4 perbedaannya tidak terlalu signifikan.

Selain $\mathrm{pH}$, salinitas juga merupakan parameter penting yang mempengaruhi kondisi mangrove. Salinitas air berkisar antara 5,68-30,5 \%o. Nilai salinitas air yang tertinggi terdapat di daerah Teluk Lamong. Rentang salinitas di Stasiun I antara 23,8-30,5 \%o. Stasiun II antara 19,6-20,9 \%. Stasiun III antara 5,68-22,2 \%o Berdasarkan penelitian sebelumnya [5], salinitas perairan pada daerah Wonorejo berkisar antara $12 \%$. Nilai salinitas ini merupakan kisaran optimal untuk pertumbuhan mangrove, karena mangrove dapat tumbuh baik dengn struktur vegetasi tertentu pada salinitas 5-35\% [6]. Secara langsung, salinitas dapat mempengaruhi laju pertumbuhan dan zonasi mangrove.

\section{KESIMPULAN DAN SARAN}

Berdasarkan hasil penelitian tugas akhir ini, dapat disimpulkan sebagai berikut :

Korelasi antara NDVI dengan nilai Spektral Ground yaitu $82 \%$. Hasil korelasi tersebut termasuk korelasi sangat kuat $(0,80-1,00)$. Koefisien korelasi bertanda positif artinya hubungan nilai NDVI pada citra dengan Spektral Ground satu arah, sehingga jika nilai NDVI tinggi (kesehatan vegetasi normal), maka nilai Spektral Ground juga semakin tinggi.

Dari hasil klasifikasi kesehatan vegetasi mangrove berdasarkan nilai NDVI didapatkan kelas vegetasi mangrove dengan kondisi kesehatan rusak $70 \%$ yang didominasi pada Kecamatan Krembangan, Sangat Buruk $17 \%$ terletak di Kecamatan Kenjeran, Buruk $7 \%$ terletak di Kecamatan Mulyorrejo, dan Normal 5,3\% terletak di Kecamatan Rungkut dan Gunung Anyar. 


\section{DAFTAR PUSTAKA}

[1] Ecoton, 1998. Panduan Pengenalan Ekosistem Mangrove Pantai Timur Surabaya. Ekoton. Surabaya.

[2] Arisandi, P., 2004. Mangrove Pantai Timur Surabaya Terancam Punah. Ecoton. Surabaya

[3] Danoedoro, P. 1996. Pengolahan Citra Digital Teori dan Aplikasinya dalam Bidang Penginderaan Jauh. Yogyakarta: Fakultas Geografi, Universitas Gajah Mada, Yogyakarta.
[4] http://endeleo.vgt.vito.be/dataproducts.html [5] Yuliati, E.A. 2010. Analisa Perubahan Ekosistem di Pantai Surabaya-Sidoarjo Pasca Pembangunan Jembatan Suramadu dan Peristiwa Lapindo dengan Citra Multitemporal. Surabaya: Institut Teknologi Sepuluh Nopember.

[6] Bengen, Dietriech G. 2004. Pedoman Teknis Pengenalan dan Pengelolaan Ekosistem Mangrove, Pusat kajian Sumberdaya Pesisir dan Lautan IPB, Bogor. 